The Chittagong Univ. J. B. Sci.,Vol. 4(1 \&2):99-105, 2009.

\title{
NUTRITIVE AND BACTERIOLOGICAL ANALYSIS OF DIFFERENT TYPES OF CHEESE
}

J.FERDOUSE, M.T. HOSSAIN AND M. N. ANWAR ${ }^{1}$

Department of Microbiology, University of Chittagong, Chittagong-4331, Bangladesh.

\begin{abstract}
In the present investigation five cheese samples were collected and their $\mathrm{pH}$ and moisture contents were determined which was found to vary from 6.0 to 6.5 and $35.0-40.0 \%$ respectively. Major nutritional factors protein (1N NaOH soluble) and fat (chloroform soluble) of the samples were also analyzed and found 57.9 to $100.0 \mathrm{mg} / \mathrm{g}$ protein and $15-25 \%$ fat. The samples showed higher number of total bacterial count $\left(5.3 \times 10^{4}-2.9 \times 10^{7} \mathrm{cfu} / \mathrm{g}\right)$ than the load of Lactobacilli $\left(1.9 \times 10^{5}\right.$ $\mathrm{cfu} / \mathrm{g})$ and Streptococci $\left(2.1 \times 10^{5} \mathrm{cfu} / \mathrm{g}\right)$. All the isolates were grouped into six on the basis of their morphological and cultural features. Six isolates were selected on the basis of their morphological, cultural, physiological and biochemical characteristics. An attempt was made to identify the isolates. They were found to belong to the three genera viz. Bacillus $\left(\mathrm{S}_{1} \mathrm{X}_{3}, \mathrm{~S}_{1} \mathrm{X}_{8}, \mathrm{~S}_{2} \mathrm{Y}_{1}\right.$, and $\left.\mathrm{S}_{2} \mathrm{Y}_{2}\right)$, Staphylococcus $\left(\mathrm{S}_{1} \mathrm{X}_{7}\right)$ and Planococcus $\left(\mathrm{S}_{1} \mathrm{X}_{11}\right)$. They were provisionally identified as Bacillus fastidiosus $\left(\mathrm{S}_{1} \mathrm{X}_{3}\right)$; B. sphaericus $\left(\mathrm{S}_{1} \mathrm{X}_{8}\right) ;$ B. brevis $\left(\mathrm{S}_{2} \mathrm{Y}_{1}\right) ; B$. aminovorans $\left(\mathrm{S}_{2} \mathrm{Y}_{2}\right)$; Staphylococcus saprophyticus $\left(\mathrm{S}_{1} \mathrm{X}_{7}\right)$ and Planococcus citreus $\left(\mathrm{S}_{1} \mathrm{X}_{11}\right)$.The selected isolates were screened for their efficacy in terms of curd and cheese production.
\end{abstract}

Key words: Cheese, Curd, Microbial load, Nutritional factors.

\section{INTRODUCTION}

Milk and milk products including raw milk, pasteurized milk, ice cream, milk powder, yoghurt and cheese are very popular and ideal foods for human consumption throughout the world (Varnam and Sutherland 1994., Dubey and Maheshwari 1999).Cheese can be defined as a solid food product made from the curdled of the milk. The milk is curdled using some combination of rennet and acidification (FDA 1949). Microorganism acidifies the milk and plays a role in texture and flavor of cheese (Weimer et al. 1999). In general, cheese having a great deal of calcium, protein, moisture, salt, fat and many other minerals. All these factors contribute to the microbial stability of cheese (Porter and Hotchkiss 1995). In a variety of ways various microorganisms are associated with cheese which may influence the quality, availability and quantity of cheese (Pelczar et al.

${ }^{1}$ Corresponding author. 
FERDOUSE ET AL.

1993). Two main groups of bacteria are involved in cheese, first groups are starter bacteria and the second groups are adventitious microorganisms from the environment which contaminate the cheese. This group includes Micrococcus, Staphylococcus, Bacillus, E-coli and many other organisms (Hoque et al. 1999, Cosentino et al. 1997, Bareak et al. 1993, Robbs et al. 1993).

A number of reports are available on the processing, nutritional value, microbial association of cheese and their probiotic activity in different corners of the world. But a few reports are available in Bangladesh. Considering the above facts, the present investigation was undertaken to determine the nutritional factors, microbial load of local and foreign cheese and also the ability of isolates to produce curd and cheese.

\section{MATERIALS AND METHODS}

\section{Collection of Samples}

The samples of cheese were collected from different shops of Chittagong and Dhaka (Table-1) and preserve at $4^{0} \mathrm{C}$ in the laboratory.

Determination of the $\mathrm{pH}$ and moisture contents of the samples

The $\mathrm{pH}$ and moisture content of the collected cheese samples were determined by applying traditional laboratory methods.

\section{Nutritive Analysis of Cheese Samples}

Major nutritional factors of these cheese samples were also analyzed. Protein content of the cheese determined by Lowry method (Lowry et al. 1951). For the determination of chloroform soluble fat we used Raghuramulu et al. method (1983) with a little modification. One gm of sample was crushed in $10 \mathrm{ml}$ of chloroform and allowed to stay for 1 hour. Then the chloroform layer was separated. The process repeated thrice, chloroform extracts poured together in vial and kept open. When the extract was reduced to $1 \mathrm{ml}$, it was transferred in preweighed small size screw cap tube and allowed to dry. Again the screw cap tube was weighed and finds out the difference between final and previous weight that indicates the weight of chloroform extract fat of cheese.

\section{Enumeration of Bacteria}

Ten-fold serial dilution and pour plate technique was followed for isolation and enumeration of bacteria. The total microbial load as well as Lactobacilli and Streptococci load of the samples was determined using Nutrient agar (NA), De Man Rogosa Sharpe (MRS) agar and Yeast Glucose Lemco Agar (YGLA) media respectively. 


\section{ANALYSIS OF DIFFERENT TYPES OF CHEESE}

\section{Isolation and Identification of the bacteria from samples}

The selected bacterial colony were isolated on the basis of their colony morphology and identified on the basis of their morphological, cultural, physiological and biochemical characteristics etc. All the characteristics were compared with the standard description of Bergey'Mannual of Determinative Bacteriology, $8^{\text {th }}$ edition (Buchanan and Gibbons 1974).

\section{Screening of the efficient isolates for cheese production}

The identified isolates were screened for their efficacy in terms of the formation of curd and cheese. For the production of cheese, the Foster et al. (1958) method was followed.

\section{RESULTS AND DISCUSSIONS}

The $\mathrm{pH}$ and moisture content of the cheese samples were determined (Table-1). All the samples were found to be acidic with a $\mathrm{pH}$ range of 6.0 to 6.5 and the moisture content of the samples was found within the range of 35.0 to $40.0 \%$. Major nutritional factors protein $(1 \mathrm{~N} \mathrm{NaOH}$ soluble) and fat (chloroform soluble) of the samples were analyzed and found 57.9 to $100.0 \mathrm{mg} / \mathrm{g} \& 15-25 \%$ respectively. No considerable differences in chloroform soluble fat content of the samples were recorded whereas the protein content was found higher in foreign cheese than the local samples (Table-1).

TABLE 1: DETERMINATION OF pH, MOISTURE AND NUTRITIONAL FACTORS (PROTEIN AND FAT) OF COLLECTED CHEESE SAMPLES.

\begin{tabular}{|c|c|c|c|c|c|c|}
\hline $\begin{array}{l}\text { No. of } \\
\text { Sample }\end{array}$ & $\begin{array}{c}\text { Description of } \\
\text { Sample }\end{array}$ & Place of Collection & $\mathrm{pH}$ & $\begin{array}{c}\text { Moisture } \\
\text { Content (\%) }\end{array}$ & $\begin{array}{l}\text { Protein } \\
(\mathrm{mg} / \mathrm{g})\end{array}$ & Fat (\%) \\
\hline 1 & $\begin{array}{c}\text { Local Cottage } \\
\text { Cheese }\end{array}$ & $\begin{array}{l}\text { Reazuddin Bazar, } \\
\text { Chittagong }\end{array}$ & 6.0 & 38.5 & 58.8 & 25 \\
\hline 2 & Kisan Cheese & $\begin{array}{l}\text { Narayangonj, } \\
\text { Dhaka }\end{array}$ & 6.2 & 39.2 & 70.0 & 17 \\
\hline 3 & $\begin{array}{l}\text { Milk Vita } \\
\text { Cheese }\end{array}$ & $\begin{array}{l}\text { GEC Circle, } \\
\text { Chittagong }\end{array}$ & 6.3 & 40.0 & 57.9 & 15 \\
\hline 4 & $\begin{array}{c}\text { Sliced Anchor } \\
\text { Cheese(New } \\
\text { Zealand) }\end{array}$ & $\begin{array}{c}\text { Kamal Store, } \\
\text { Chittagong }\end{array}$ & 6.0 & 36.8 & 80.4 & 17 \\
\hline 5 & $\begin{array}{c}\text { Mozzarella } \\
\text { Cheese } \\
\text { (Italian) }\end{array}$ & $\begin{array}{c}\text { Kamal Store, } \\
\text { Chittagong }\end{array}$ & 6.5 & 35.0 & 100.0 & 22 \\
\hline
\end{tabular}


FERDOUSE ET AL.

Frau et al. (1997) proposed that the fat contents of industrially manufactured cheese was significantly different from those in traditionally manufactured cheese $(\mathrm{P}<0.001)$ Anonymous 1998, reported that protein content was a little higher in foreign cheese than that of local one. Our results are in concurrence with the above findings. Besides, Taleb et al. (1995) pointed out the chemical changes in protein fraction during maturation of cheese.

In the present study it was found that local cheese showed higher total bacterial count than the foreign samples. Besides, cheese samples showed higher number of total bacterial count $\left(5.3 \times 10^{4}-2.9 \times 10^{7} \mathrm{cfu} / \mathrm{g}\right)$ than the load of Lactobacilli $\left(1.9 \times 10^{5} \mathrm{cfu} / \mathrm{g}\right)$ and Streptococci $\left(2.1 \times 10^{5} \mathrm{cfu} / \mathrm{g}\right)$ (Table2).Lactobacilli and Streptococci are useful for cheese production, cheese moisture retention and also for probiotic activity. (Low et al.1998, Benech et al. 2003, Songisepp et al. 2004.)

TABLE 2: THE TOTAL BACTERIAL LOAD OF CHEESE SAMPLES.

\begin{tabular}{clccc}
\hline \multirow{2}{*}{$\begin{array}{c}\text { No. of } \\
\text { Sample }\end{array}$} & Description of Sample & \multicolumn{3}{c}{ Total bacterial count (cfu/g) } \\
\cline { 3 - 5 } & & NA & MRS & YGLA \\
\hline 1 & Local Cottage Cheese & $9.3 \times 10^{5}$ & $2.3 \times 10^{3}$ & $2.1 \times 10^{5}$ \\
2 & Kisan Cheese & $2.9 \times 10^{7}$ & $1.9 \times 10^{5}$ & $8.0 \times 10^{3}$ \\
3 & Milk Vita Cheese & $3.1 \times 10^{5}$ & $2.3 \times 10^{4}$ & $5.3 \times 10^{4}$ \\
4 & Sliced Anchor Cheese & $5.3 \times 10^{4}$ & $5.2 \times 10^{4}$ & $2.1 \times 10^{4}$ \\
5 & Mozzarella Cheese & $2.5 \times 10^{6}$ & $2.7 \times 10^{3}$ & $2.1 \times 10^{3}$ \\
\hline
\end{tabular}

During the period of study, six isolates were selected on the basis of their morphological, cultural, physiological and biochemical characteristics. An attempt was made to identify the isolates by conventional method. They were found to belong to the three genera viz. Bacillus $\left(\mathrm{S}_{1} \mathrm{X}_{3}, \mathrm{~S}_{1} \mathrm{X}_{8}, \mathrm{~S}_{2} \mathrm{Y}_{1}, \mathrm{~S}_{2} \mathrm{Y}_{2}\right)$, Staphylococcus $\left(\mathrm{S}_{1} \mathrm{X}_{7}\right)$ and Planococcus $\left(\mathrm{S}_{1} \mathrm{X}_{11}\right)$. They were provisionally identified as the following species: Bacillus. fastidiosus $\left(\mathrm{S}_{1} \mathrm{X}_{3}\right) ;$ B. sphaericus $\left(\mathrm{S}_{1} \mathrm{X}_{8}\right) ;$ B. brevis $\left(\mathrm{S}_{2} \mathrm{Y}_{1}\right) ;$ B. aminovorans $\left(\mathrm{S}_{2} \mathrm{Y}_{2}\right)$; Staphylococcus saprophyticus $\left(\mathrm{S}_{1} \mathrm{X}_{7}\right)$ and Planococcus citreus $\left(\mathrm{S}_{1} \mathrm{X}_{11}\right)$ compared with the standard description of Bergey'Mannual of Determinative Bacteriology, $8^{\text {th }}$ edition (Buchanan and Gibbons 1974). 


\section{ANALYSIS OF DIFFERENT TYPES OF CHEESE}

In this study the efficacy of curd formation and cheese production by the selected isolates are shown in Table-3.

TABLE 3: CURD AND CHEESE PRODUCTION BY THE SELECTED ISOLATES.

\begin{tabular}{cccccc}
\hline Isolates No. & $\begin{array}{c}\text { Curd } \\
\text { Formation }\end{array}$ & $\begin{array}{c}\text { Time of } \\
\text { Curdling }\end{array}$ & $\begin{array}{c}\text { Amount of } \\
\text { Whey }\end{array}$ & $\begin{array}{c}\text { Colors of } \\
\text { Cheese }\end{array}$ & $\begin{array}{c}\text { Dry weight of } \\
\text { Cheese(gm) }\end{array}$ \\
\hline $\mathrm{S}_{1} \mathrm{X}_{11}$ & - & - & - & - & - \\
$\mathrm{S}_{1} \mathrm{X}_{3}$ & + & 2-3days & ++ & Cream & 1.3 \\
$\mathrm{~S}_{1} \mathrm{X}_{7}$ & + & 2-3days & ++ & Cream & 2.0 \\
$\mathrm{~S}_{1} \mathrm{X}_{8}$ & + & 3-4days & ++ & Cream & 1.5 \\
$\mathrm{~S}_{2} \mathrm{Y}_{1}$ & + & 4days & + & Cream & 0.9 \\
$\mathrm{~S}_{2} \mathrm{Y}_{2}$ & + & 3-4days & ++ & Cream & 1.0 \\
\hline Note: '+'= Positive ('+' as scantly, '++' as moderate, '+++' as heavy) and '_'=
\end{tabular}

Negative.

Among the isolates Planococcus citreus $\left(\mathrm{S}_{1} \mathrm{X}_{11}\right)$ was unable to produce any curd and cheese. However Bacillus fastidiosus $\left(\mathrm{S}_{1} \mathrm{X}_{3}\right)$, B. sphaericus $\left(\mathrm{S}_{1} \mathrm{X}_{8}\right)$, B. brevis $\left(\mathrm{S}_{2} \mathrm{Y}_{1}\right)$, B. aminovorans $\left(\mathrm{S}_{2} \mathrm{Y}_{2}\right)$ and Staphylococcus saprophyticus $\left(\mathrm{S}_{1} \mathrm{X}_{7}\right)$ were able to produce very little amount of curd and cheese which are not suitable for commercial use.

In the early part of this century, scientists and commercial companies began to investigate cheese starters (natural) and examine the organisms they contained. As one would accept, in addition to the lactic acid bacteria it was found that there were a number of undesirable contaminants. These undesirable bacteria might arise in cheese as a result of contamination during handling and processing. Robbs et al. (1993) reported the behavior of Staphylococcus aureus in parmesan cheese during production and storage. Raw milk, plant floor, processing water was the main source of bacterial contamination in cheese (Sabeha and Rashid 1988). So, in the present study, the members of the genus Bacillus, Planococcus and Staphylococcus that were recorded in cheese may be the contaminating microbes. Cosentino et al. (1997) reported the frequency and level of Bacillus sp. contamination in dairy products. Recently Hoque et al. (1999) studied the occurrence of Staphylococcus aureus in milk products. The results of present investigation are in concurrence with the results of Cosentino et al. (1997) and Hoque et al. (1999).

\section{REFERENCES}

ANONYMOUS 1998. A Bacteriological study of Cheese. M.Sc Thesis, Department of Botany, University of Dhaka, Bangladesh. 
BAREAK, M. A, HOQUE, M.M. AND KHAN, M.R. 1993. Detection of Staphylococcus aureus, Bacillus cereus and Streptococcus spp. in locally available milk products. Dhaka. Univ. J. Biol. Sci. 2: 81-85.

BENECH, R. O., KHEADR, E.E., LACROIX, C AND FLISS, I. 2003. Impact of nisin producing culture and liposome-encapsulated nisin on ripening of Lactobacillus added Chedder cheese. J. Dairy Sci. 86:1895-1909.

BUCHANAN, R. E AND GIBBONS, N. E. 1974. Bergey's Manual of Determinative bacteriology. $\left(8^{\text {th }}\right.$ ed.) The Williams and Wilkins Co. Baltimore, USA.

COSEntino, S., MUlargia, A. F., PISANO, B., TUBERI, P. AND PALMAS, F. 1997.

Incidence and biochemical characteristics of Bacillus flora in sardini and dairy products. Inter. J. Food Microbiol. 38(2-3): 235-238.

DUBEY, R.C AND MAHESHWARI, D.K. 1999. A Text book of Microbiology $\left(1^{\text {st }}\right.$ edition). S. Chand \& Company Ltd. (publisher). NewDelhi, India.

FDA (Food and Drug Administration) 1949. Department of Agriculture. U.S.A.

FOSTER, E.M., NELSON, F.E., SPECK, M.L., DOETSCH, R.N AND OLSON, J.C. 1958. Dairy Microbiology. MacMillan \& Co Ltd. London. pp: 334408.

FRAU, M., SIMAL, S., FEMENIA, A. AND ROSSELLO, C.1997. Application of principal component analysis to chemical characteristics of Mahon cheese. Zeitselrift fure lebensmiflet- untersuchung and forschung. 205 (6): $429-432$.

HOQUE, M.M., NATH, D.R., CHOWDHURY, S.A., RAHMAN, S. AND NASIMUZZAMAN, M. 1999. Occurrence of Staphylococcus aureus in fast food and milk sample of Dhaka city. Bangladesh. J. Microbial. 16(1):69-76.

LOW, D., AHLGREN, J.A., HORNE, D., MCMAHON, D.J., OBERG, C.J. and BROADBENT, J.R. 1998. Role of Streptococcus thermophilus MR-1C capsular exopolysaccharide in cheese moisture retention. J. Appl. Environ. Microbiol. 64(4): 2147-2151.

LOWRY, O.H., ROSEBROUGH, N. J., FARR, A.F. AND RANDALL, R.J. 1951. Protein measurement with the folin - reagent. J. Biol. Chem. 193: 265-275.

PELCZAR, M.J., CHAN, E.C.S. AND. KRIEG, N.R. 1993. Microbiology (5 $^{\text {th }}$ ed.).TATA McGraw-Hill Book Company, New York. pp: 418-443.

PORTER, N.N AND HOTCHKISS, J.H. 1995. Food Science (Fifth edition). CBS Publishers. pp 300-314. 
ANALYSIS OF DIFFERENT TYPES OF CHEESE

RAGHURAMULU, N., MADHAVAN, N.K. AND KALYANA, S. 1983. A manual of laboratory techniques. NIN, Indian Council of Medical Research, India. pp: 80-87.

ROBBS, P.G., BARBOSA, C.G. AND FAVARIN, V. 1993. Behavior of Staphylococcus aureus and E. coli and injury formation during production and storage of parmesan cheese. Rev. Microbiol. 24(2): 111-117.

SABEHA, M.A. AND RASHID, M.M. 1988. Bacterial contamination of soft white cheese and cheese processing plant with special reference to psychrophilic Pseudomonas. J. Biol. Sci. Res. 19(1): 1-12.

SONGISEPP, E., KULlISAAR, T., HUTT, P., ELIAS, P., BRILENE, T., ZILMER, M. AND MIKELSAAR, M. 2004. A new probiotic cheese with antioxidative and antimicrobial activity. J. Dairy Sci. 87: 2017-2023.

TALEB, A., ISHAK, S.R. AND GAZZAR, W. Et. 1995. Chemical changes in protein fractions during maturation of Domiati cheese manufactured by different techniques. J. Agric. Sci. 19 (9): 2945-2952.

VARNAM, A.H. AND SUTHERLAND, J.P. 1994. Milk and Milk product technology, Chemistry and Microbiology, ( $3^{\text {rd }}$ edition) Chapman \& Hall. pp: 213-234.

WEIMER, B., SEEFELDT, K. AND DIAS, B. 1999. Sulfur metabolism in bacteria associated with cheese. J. Food Sci. 76(4): 247-261.

Manuscript received on 8.7.09; Accepted on 22.12. 09

The Chittagong University Journal of Biological Sciences, Vol.4 ( 1 \& 2): Page no : 99 -105 